\title{
Fabrication and Mechanical Properties of Sintered Leucite Body
}

\author{
Shinobu HASHIMOTO, Fumiharu SATO, Sawao HONDA, Hideo AWAJI and Koichiro FUKUDA \\ Materials Science and Engineering, Nagoya Institute of Technology, Gokiso-cho, Showa-ku, Nagoya-shi 466-8555
}

\author{
リューサイト焼結体の作製とその機械的特性 \\ 橋本＼cjkstart忍·佐藤史治·本多沢雄 ·淡路英夫 · 福田功一郎 \\ 名古屋工業大学大学院工学研究科物質工学専攻, 466-8555 名古屋市昭和区御器所町
}

\begin{abstract}
Fine leucite powder with an average diameter of $0.2 \mu \mathrm{m}$ was fabricated by the low-temperature synthesis method for leucite using natural mineral potash feldspar as the major raw material, followed by ball milling. A sintered leucite body with a $99.0 \%$ relative density was obtained by heating the leucite powder cylindrical pellet at $1250^{\circ} \mathrm{C}$ for $1 \mathrm{~h}$. The mechanical properties of this dense leucite body were determined. The bending strength, fracture toughness, elastic modulus and Vickers hardness of the body were $173 \mathrm{MPa}, 2.3 \mathrm{MPa} \cdot \mathrm{m}^{1 / 2}, 63 \mathrm{GPa}$ and 5.3 GPa, respectively.

[Received January 31, 2005; Accepted May 19, 2005]
\end{abstract}

Key-words : Synthesis, Sintering, Leucite, Potash feldspar, Mechanical properties

\section{Introduction}

Leucite, a mineral composed of potassium and aluminum metasilicate $\left(\mathrm{KAlSi}_{2} \mathrm{O}_{6}\right)$, has a high melting point $\left(1693^{\circ} \mathrm{C}\right)^{1)}$ and a high linear thermal expansion coefficient of $1-2 \times$ $10^{-5} / \mathrm{K}$ (till $\left.600^{\circ} \mathrm{C}\right) .^{2)}$ Furthermore, this material has an aesthetic property and a superior biocompatibility, so that it is expected for use as a biomaterial. Leucite is precipitated in artificial tooth glass porcelain composed of potash feldspar $\left(\mathrm{KAlSi}_{3} \mathrm{O}_{8}\right)$ as a main component by heat treatment. ${ }^{3)}$ The improved mechanical properties of artificial tooth glass porcelain with leucite is presumed to be due to prestress caused by the difference in thermal expansion between leucite and matrix potash feldspar ${ }^{2)}$ or to the high strength of pure leucite. However, the mechanical properties of pure leucite have not yet been estimated, since it is hard to synthesize a pure dense leucite polycrystalline body. Generally, the normal method of synthesizing leucite polycrystal is by heating starting materials up to the melting point of leucite followed by gradual cooling to room temperature. ${ }^{4)}$ Recently, we have developed a lowtemperature synthesis method for leucite crystal using a powder mixture consisting of $\mathrm{K}_{2} \mathrm{SO}_{4}, \mathrm{Al}_{2}\left(\mathrm{SO}_{4}\right)_{3}$ and $\mathrm{SiO}_{2}$. In this method, leucite crystal can be obtained at a relatively low temperature of $1000^{\circ} \mathrm{C} .{ }^{5)}$ In addition, we have developed a method of synthesizing leucite polycrystal at $1100^{\circ} \mathrm{C}$ using natural mineral potash feldspar as raw material. ${ }^{6}$

In this study, leucite powder was fabricated using the lowtemperature synthesis technique with potash feldspar as raw material, and its sintering behavior was clarified. The dense leucite body obtained was analyzed of its mechanical properties, namely, fracture strength, fracture toughness, elastic modulus and Vickers hardness. The results were compared with those of dense potash feldspar.

\section{Experimental}

Reagent-grade $\mathrm{Al}_{2}\left(\mathrm{SO}_{4}\right)_{3} \cdot 14-18 \mathrm{H}_{2} \mathrm{O}, \mathrm{K}_{2} \mathrm{SO}_{4}$ and natural mineral Kanamaru potash feldspar (Sekikawa, Niigata) were used as raw materials. The chemical composition of the Kanamaru potash feldspar is shown in Table 1. The aluminum sulfate hydrate was calcined at $300^{\circ} \mathrm{C}$ for $12 \mathrm{~h}$ to form $\mathrm{Al}_{2}\left(\mathrm{SO}_{4}\right)_{3}$. Starting powder mixture consisting of $\mathrm{Al}_{2}\left(\mathrm{SO}_{4}\right)_{3}$ : Kanamaru potash feldspar: $\mathrm{K}_{2} \mathrm{SO}_{4}$ in the ratio of $3: 3: 15$ (mass\%) was mixed thoroughly and placed in an alumina crucible. The crucible was covered with an alumina lid and heated at $1100^{\circ} \mathrm{C}$ for $3 \mathrm{~h}$. The electric power was then turned off, to naturally cool the crucible to room temperature. The heating rate of the furnace was $10^{\circ} \mathrm{C} / \mathrm{min}$. After heating, the reactant at the bottom of the crucible was soaked in 3\% $\mathrm{HCl}$ at $70-80^{\circ} \mathrm{C}$ for a period of $0.5-1 \mathrm{~h}$. After the reactant was washed with water and dried, a white powder was obtained as a final product. The crystalline phase of the obtained powder was examined by X-ray diffraction (XRD; XD-D1, Shimadzu Co.) analysis. The powder was confirmed to be leucite and ground by ball milling for $24 \mathrm{~h}$ using alumina balls of $2 \mathrm{~mm}$ diameter to obtain fine leucite particles. The specific surface area of the fine leucite particles was measured by the BET method using a nitrogen absorption device (NOVA1000,

Table 1. Chemical Composition of Potash Feldspar Used (mass\%)

\begin{tabular}{lc}
\hline $\mathrm{SiO}_{2}$ & 68.0 \\
$\mathrm{Al}_{2} \mathrm{O}_{3}$ & 18.0 \\
$\mathrm{Fe}_{2} \mathrm{O}_{3}$ & 0.11 \\
$\mathrm{TiO}_{2}$ & 0.02 \\
$\mathrm{CaO}$ & 0.12 \\
$\mathrm{MgO}$ & 0.31 \\
$\mathrm{~K}_{2} \mathrm{O}$ & 13.0 \\
$\mathrm{Na}_{2} \mathrm{O}$ & 1.20 \\
$\mathrm{Rb}_{2} \mathrm{O}$ & 0.11 \\
$\mathrm{Ir}_{2} \mathrm{O}_{3}$ & $\mathbf{0 . 0 2}$ \\
$\mathrm{PbO}$ & 0.01 \\
$\mathrm{SO}$ & 0.01 \\
$\mathrm{Cl}$ & 0.02 \\
\hline $\mathrm{Total}_{3}$ & 100.93 \\
\hline
\end{tabular}




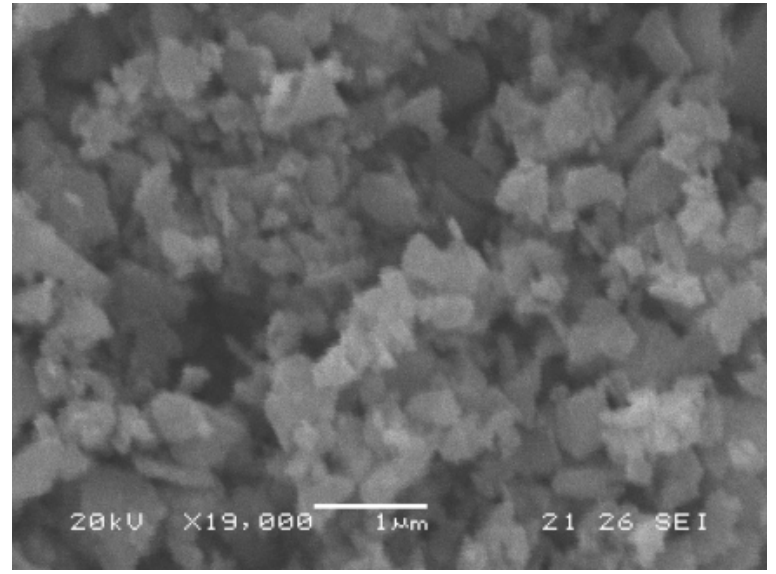

Fig. 1. SEM image of fine leucite powder after ball-milling for $24 \mathrm{~h}$.

Yuasa Ionics Inc.). Furthermore, the average diameter of the leucite particles was calculated from the BET result. The microstructure of the particles was observed by scanning electron microscopy (SEM; JEOL5200, JEOL). The particles were pressed at $50 \mathrm{MPa}$ into a cylindrical pellet $15 \mathrm{~mm}$ in diameter and $5 \mathrm{~mm}$ in height. The pellet was cold isostatically pressed (CIP) at $100 \mathrm{MPa}$ using water as the medium and heated at $1150-1300^{\circ} \mathrm{C}$ for $1 \mathrm{~h}$ in an electric furnace. The heating and cooling rates were $10^{\circ} \mathrm{C} / \mathrm{min}$. The density was determined using the Archimedean method for bulk density and a pycnometer for intrinsic density; relative density was determined from these values. The mechanical properties, such as three-point bending strength (DSS-500, Shimadzu Co.), elastic modulus (LUM-77KS, Tungaloy Co.), Vickers hardness, fracture toughness (AKV-A, Akashi Seisakusyo), and linear thermal expansion (TMA-50, Shimadzu Co.) of the sintered leucite body were estimated. For comparison with the leucite body, a cylindrical pellet of dense potash feldspar was also fabricated under the same conditions and sintered at $1150^{\circ} \mathrm{C}$ for $1 \mathrm{~h}$. Its mechanical properties were also estimated. The fracture surfaces of dense leucite bodies were observed using SEM to clarify the sintering behavior.

\section{Results and discussion}

Figure 1 shows a SEM image of the fine leucite particles after the ball milling. The average size and specific surface area of the leucite particles were $0.2 \mu \mathrm{m}$ and $11.6 \mathrm{~m}^{2} / \mathrm{g}$, respectively. This size was confirmed from the image. The change in the relative density of the leucite pellet with heating temperature is shown in Fig. 2. The relative density of the leucite pellet increased with increasing temperature and reached a maximum of $99.0 \%$ at $1250^{\circ} \mathrm{C}$. However, the relative density decreased at $1300^{\circ} \mathrm{C}$, which could be due to structural changes during high-temperature heating. Figure 3 shows SEM images of the fractured surfaces of the leucite bodies heated in the range of $1150-1300^{\circ} \mathrm{C}$ for $1 \mathrm{~h}$ with a temperature interval of $50^{\circ} \mathrm{C}$. At $1150^{\circ} \mathrm{C}$, many pores of $7-10 \mu \mathrm{m}$ diameter were observed. However, at 1200 and $1250^{\circ} \mathrm{C}$, no pores were observed in the bodies. At $1300^{\circ} \mathrm{C}$, pores of $5-10 \mu \mathrm{m}$ diameter were observed in the bodies formed by the evaporation of volatile components. Hence, the decrease in the relative density at $1300^{\circ} \mathrm{C}$ can be attributed to the formation of gaseous species in the sintered body. From Table 1, natural potash feldspar has impurities, such as $\mathrm{SO}_{3}$ and $\mathrm{Cl}$. Therefore, at $1300^{\circ} \mathrm{C}$, sulfate and/or chloride as impurities in potash feldspar show a

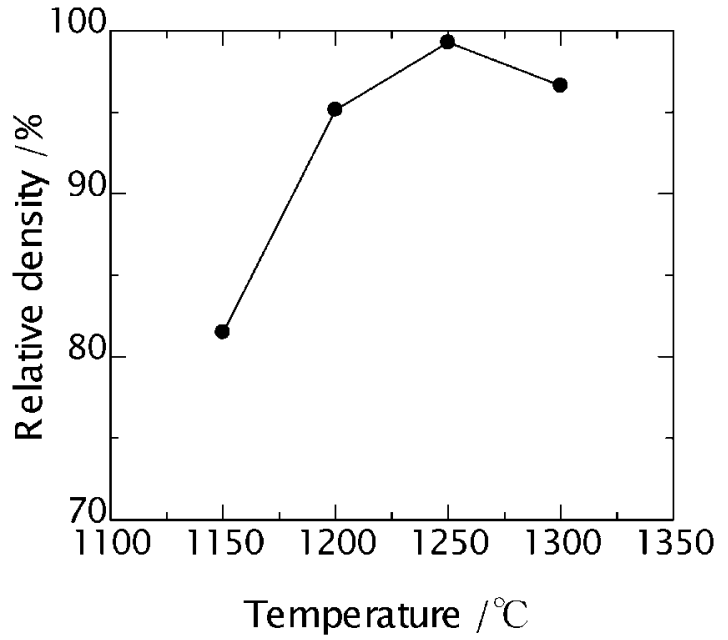

Fig. 2. Change in relative density of leucite compact with heating temperature for $1 \mathrm{~h}$.

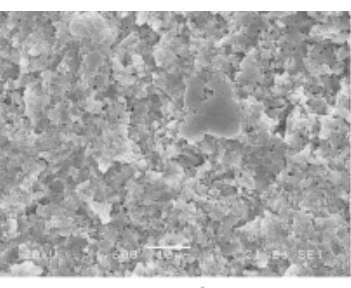

$1150^{\circ} \mathrm{C}$

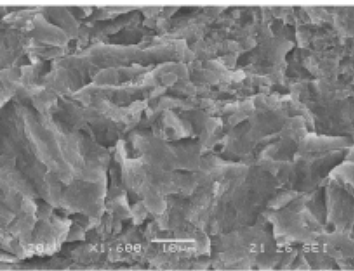

$1250^{\circ} \mathrm{C}$

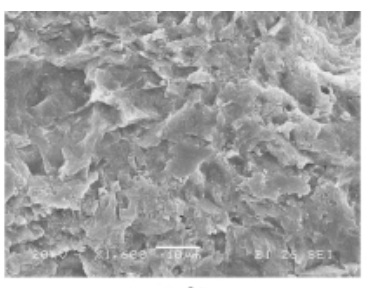

$1200^{\circ} \mathrm{C}$

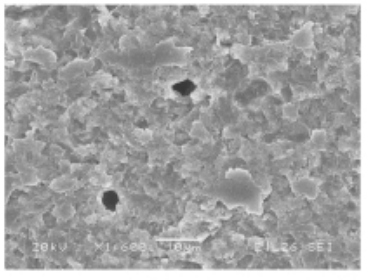

$1300^{\circ} \mathrm{C} \quad 10 \mu \mathrm{m}$
Fig. 3. SEM images of fractured surfaces of leucite compacts after heating at $1150-1300^{\circ} \mathrm{C}$ for $1 \mathrm{~h}$.

tendency to vaporize, ${ }^{7)}$ resulting in the formation of few pores thereby decreasing the relative density. In addition, there is a possibility that the abnormal grain growth of leucite occurs during heating at a high temperature $\left(1300^{\circ} \mathrm{C}\right)$, thereby decreasing the relative density. On the other hand, the relative density of potash feldspar was $96 \%$ after heating at $1150^{\circ} \mathrm{C}$ for $1 \mathrm{~h}$. Figure 4 shows linear thermal expansion curves of the dense leucite and dense potash feldspar bodies. The leucite body showed a linear thermal expansion coefficient of $2.3 \times$ $10^{-5} / \mathrm{K}$ from room temperature to $600^{\circ} \mathrm{C}$. This was almost the same as the previous report. ${ }^{2)}$ After $660^{\circ} \mathrm{C}$, the expansion curve of the leucite body had a gentle slope due to the transformation of leucite from the tetragonal phase to the cubic phase. ${ }^{2)}$ Therefore, the linear thermal expansion coefficient was $1.7 \times 10^{-5} / \mathrm{K}$ in the range of room temperature to $1000^{\circ} \mathrm{C}$. On the other hand, the linear thermal expansion curve of the dense potash feldspar body monotonically increased from room temperature to $1000^{\circ} \mathrm{C}$. The linear thermal coefficient of the feldspar body was $6.1 \times 10^{-6} / \mathrm{K}$. The mechanical properties of the dense leucite and potash feldspar bodies are presented in Table 2. It is clear from these results that the elastic 


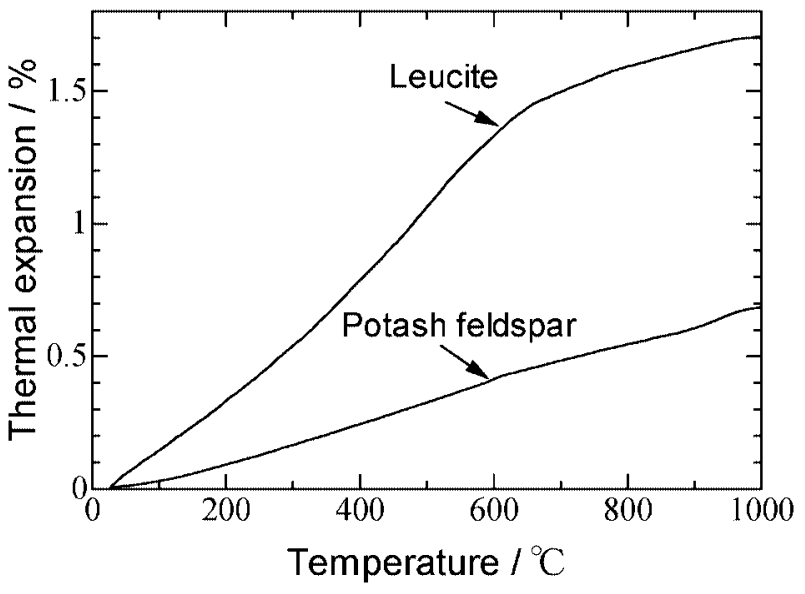

Fig. 4. Linear thermal expansion curves of dense leucite and dense potash feldspar bodies.

Table 2. Mechanical Properties of Dense Leucite and Dense Potash Feldspar Bodies

\section{Leucite Potash feldspar}

\begin{tabular}{ccc}
\hline Elastic modulus $(\mathrm{GPa})$ & 63 & 81 \\
Vickers hardness $(\mathrm{GPa})$ & 5.3 & 7.3 \\
Fracture toughness $\left(\mathrm{MPa} \cdot \mathrm{m}^{1 / 2}\right)$ & 2.3 & 1.5 \\
Bending strength $(\mathrm{MPa})$ & 173 & 140 \\
\hline
\end{tabular}

modulus and Vickers hardness of the dense leucite body were $63 \mathrm{GPa}$ and $5.3 \mathrm{GPa}$, respectively, which were smaller than those of the dense potash feldspar body. The bending strength and fracture toughness of the dense leucite body were observed to be $173 \mathrm{MPa}$ and $2.3 \mathrm{MPa} \cdot \mathrm{m}^{1 / 2}$, respectively, which were larger than those of the dense potash feldspar body.

\section{Conclusion}

Fine leucite powder with an average diameter of $0.2 \mu \mathrm{m}$ was synthesized by adopting a low-temperature synthesis method using natural mineral potash feldspar as raw material. A dense leucite body with a $99.0 \%$ relative density was obtained by heating the powder leucite pellet at $1250^{\circ} \mathrm{C}$ for $1 \mathrm{~h}$. The linear thermal expansion coefficient of this leucite body from room temperature to $600^{\circ} \mathrm{C}$ was $2.3 \times 10^{-5} / \mathrm{K}$. The bending strength, fracture toughness, elastic modulus and Vickers hardness of the dense leucite body were $173 \mathrm{MPa}, 2.3 \mathrm{MPa} \cdot \mathrm{m}^{1 / 2}, 63 \mathrm{GPa}$ and $5.3 \mathrm{GPa}$, respectively.

\section{References}

1) Levin, E. M., Robbins, C. R. and McMurdie, H. F., "Phase Diagram for Ceramists," Ed. by Reser, M. K., Am. Ceram. Soc., Columbus, Ohio, USA (1967) Fig. 407.

2) Ban, S., Matsuo, K., Mizutani, N., Kaikawa, K. and Hasegawa, J., J. Japan Soc. Dent. Mater. Dev., Vol. 19, pp. 318-325 (2000) [in Japanese].

3) Ban, S., Matsuo, K., Mizutani, N., Iwase, H. and Hasegawa, J., Dent. Mater. J., Vol. 17, pp. 264-274 (1998).

4) Ban, S., Matsuo, K., Mizutani, N., Tanikawa, H., Kaikawa, K. and Hasegawa, J., J. Dent. Mater. J., Vol. 18, pp. 137-143 (1999).

5) Hashimoto, S. and Yamaguchi, A., J. Ceram. Soc. Japan, Vol. 108, pp. 40-44 (2000).

6) Hashimoto, S. and Yamaguchi, A., J. Ceram. Soc. Japan, Vol. 112, pp. 242-244 (2004) [in Japanese].

7) Shiraki, Y., “Uwagusuri to Sono Ganryo," Gihodo (1968) pp. 862-862. 